\title{
THE DUTY PROBLEM IN NEGLIGENCE CASES
}

The undertaking to restate the rules and principles developed by the English and American courts finds in the field of torts a most hopeless task. A loose classification permits an infinite variety of types of conduct to be classed as torts. The rules, for most part, which govern these cases are still liquid. Only the types of conduct which are also designated crimes can be said to be subject to crystallized rules of tort law. Even here the definiteness and certainty ordinarily assumed are illusory. If this bulk of law has not yet been crystallized by the judicial process. in what manner can legal scholars speed up the process? And what is more, where are the stabilizing factors to be found?

\section{The Nature of Law}

In order to control the conduct of our neighbors and ourselves much machinery is employed. Judges, policemen, legislatures, teachers, practitioners, principles, rules, formulas, doctrines, standards-a multitude of devices too numerous to catalog. At this whole complex of government we throw the term "law," and immediately difficulties are encountered. To this term is given a host of meanings. ${ }^{1}$ It cannot be said that any of them are correct or incorrect. It is merely a matter of language. "Law" is most frequently defined as "rules recognized and acted on in courts of justice,"' "a rule of civil conduct,"3 "command of the sovereign,"4 "the sum of rules of justice administered in a state,"5 "body of rules which the courts . . . apply in deciding cases." 6 Dean Pound says, "there are three elements that make up the whole of what we call law"; (1) legal precepts, (2) traditional ideas and technique of interpreting, developing and applying legal precepts, and (3) philosophical, political and ethical ideas as to the end of law. ${ }^{7}$ Dean Wigmore says: "Law is the quality of being uniform and regular in a series of

${ }^{1}$ See Pound, The Theory of Judicial Decision (1923) 36 Harv. L. Rev. 641, 643: "Most of the discussion as to the nature of law which has been the staple of Anglo-American writing on jurisprudence has suffered from an initial false assumption that 'law' is a single conception; that the one short word has one simple analytically ascertainable meaning. As one reads the voluminous literature upon this subject he soon feels that the disputants are speaking of different things, although calling them by one name."

2 SAlmond, JuRisprudence (5th ed. 1916) §5.

31 BL. COMM. *44.

4 Austin, Jurisprudence (Student's ed. 1875) 11, 16.

- Pollock, A First Book of Jurisprudence (1896) 17, 18. c. IV.

- Gray, Nature and Sources of the Law (2d ed. 1921) 110, see generally

${ }^{7}$ Pound, op. cit. supra note 1 , at 645. 
events. . . Jural law is a rule expressing the relations of human conduct conceived as subject to realization by state force." 8

In all of these concepts the power to control conduct through passing judgment is identified with the instrumentalities through which the power itself is employed. Law is identified with the machinery of law. This is a common conception of law. To a large part of our population the policeman is "the law." And this is no stranger than the more-popular belief that "the law" consists of statutes and constitutions, nor is it any less accurate than that more sophisticated notion of the legal scholar that "the law" is to be found in the decisions of courts and in the rules, principles and standards which courts announce and employ. Each individual objectifies law with the devices with which he most frequently comes into contact. But all of these are merely the wiring and fixtures with which we equip our legal habitat. A decision of a case is no more law than the light from last night's lamp is electricity. We make use of decisions, statutes and constitutions for the purpose of developing and controlling the capacity to pass desirable judgments and employ these and scores of other devices in order to make judgments effectual. But that is their limit; they stop short of any power within themselves. By suggesting that law has been confused with the machinery through which it operates, I do not mean to minimize the importance of the machinery. My emphasis is that it is machinery. The gas engine and multiplication table are devices without price. There can be no power without machinery; there can be no law without judges and courts and rules. But machinery without power is impotent. Hence "law" as here conceived is the power of passing judgment-the power of passing judgment through formal political agencies for securing social control. ${ }^{9}$

This distinction may be nothing more than a change of emphasis,

82 Wigmore, Select Cases of the Law of Torts (1912) App. A, § 2.

${ }^{\circ}$ In attempting to articulate the judicial process in negligence cases there is no place to start save with a postulate as to the nature of law. No extended development of such a postulate is possible here. On the other hand it is essential that its outline be indicated. None of the concepts of law with which he has become acquainted permit the emphasis which the writer feels should be given to the administration of law. The power to pass judgment as the basis of social control is thus offered as a starting point from which it is possible to account for the behaviour of judges as part of a law administration system. This is not as extravagant a theory as the concept of "power" would indicate. What is power? We might as well ask what is force. What is spirit? What is electricity? What is life? Perhaps the answer for one would be the answer to all. Probably all science gets back to the same starting point here. And whether the inquiry is futile or not is beside the point. The important thing is not what power is, but how it can be utilized. Whatever assumptions we make, however high-sounding the names we give them, the upshot is this: "Here is something we use. How can we do so to the best advantage?" But this does not mean that it is not of the utmost importance to identify this power. It is. Hence, instead of starting with some such postulate as a rule or aggregate of rules, the writer starts with the power which operates through rules. This power he calls "law." 
but it seems to be one worth making. It implies in the beginning that law is indefinable and ungraspable. Politically its source may be sovereignty; religiously it may be God. These are nothing more than figures of speech by which to adjust the horizons of thought in those directions. But in so far as the sources of law are apparent, they are found in the judgments of the individuals who are entrusted with the power to pass those judgments. And this would, in turn, imply that any science of law is, at bottom, the science of the administration of law. Once this point has been reached, the major problems of such a science stand out boldly. They are: (1) a language technic, and (2) a judging technic. To these may be added, of necessity, (3) a statistical technic. ${ }^{10}$

\section{A Language Technic}

The struggle which men are making to rise above the word level seems to have no end. "The power of words is the most conservative force in our lives" say Ogden and Richards. ${ }^{11}$ Only now, if at all, is there any indication that the bonds of "holy words" are weakening. Word ritual under one guise or another has always been one of the primary methods of law administration, and the development of the uses made of words is one of the most puzzling of studies. We can scarcely realize the part which sacred words, taboo words, magic words, continue to play in our law. While historically these were among the first uses of language, nevertheless words of modern mintage frequently quickly develop these characteristics. ${ }^{12}$ No sooner had the written word become

${ }^{10}$ No business can be operated successfully without its accounting department. Yet here is the largest business in America with no means at hand for seeing itself in operation. Little wonder it functions so poorly. Nothing speaks so highly for the soundness of our society as this ability to survive without knowing how or what society's chief protective organism is doing. How can courts modify their practices or legislatures make changes without the knowledge of results achieved from day to day by the machinery in operation? When no one knows, one person's guess is as good as another's. Guesses must give way here to facts. Something can be gained from borrowing the statistical methods of the other social sciences, but the job will probably require the development of a technic suited to the particular difficulties of law administration. The various crime surveys of the past few years look in this direction. And it is of more than passing significance that the foundations are beginning to see the opportunities which are open at this point. Of necessity there will be many trials and errors before a pattern is developed which will lay open the results our legal machinery is producing, but that the pattern must be developed is too obvious for debate.

11 Ogden \& Richards, Meaning of Meaning (1925) 25.

12 The term "duty" for instance is a relatively new term. Is it merely a symbol, or has it some "inherent" meaning which makes it sacred? Clearly as employed in legal science it is a symbol, such as "right," "immunity" and others like them designed to reduce to a single word a network of ideas. Yet I have heard intelligent lawyers talk most earnestly of "duty" as the most sacred word in the language save "God," and develop an extravaganza as to how those other sacred words "mother" and "country" are themselves dependent upon "duty." Doubtless every such term as "right," "contract," "liberty," "property," "constitution," and numerous others, gathers the same sort of emotive qualities. What can legal science do when its terminology becomes thus gummed? There is no other science which has quite the same degree of difficulty in immunizing its language. 
a means of evidencing the dealings of men in every day life than it was shackled by all of these uses. The period of word ritual is not far back in our legal history. ${ }^{13}$ The "oath" hangs onto our procedure with unbelievable tenacity, and generations are required to rid our administration of any formalism. Nor do we seem to make much progress here. ${ }^{14}$ The succeeding stages of rules and principles and doctrines, with their formulas and standards reduced to well polished phrases, are still dominating our law. Probably these are even now at high tide. To this array of theological methods we have added classification and analysis, the deductive and inductive processess of logic. And with these as a basis have come attempts at perfecting a mechanics of symbols by which our rules may be made to work as precisely as the devices of numbers. ${ }^{15}$ All of these have their utility, but the first requisite of intellectual freedom, and as much so in the study of the science of law as elsewhere, is a wholesome fear of words.

Fortunately for the common law there are strong currents which tend to sweep its channels clear as fast as the crystallization brought about by words threatens to choke them. The common law system of administration at first had no adequate machinery for preserving with certainy and precision the words of its judges. Their reported sayings were therefore quickly weakened when reporters were found in conflict or otherwise unreliable. Moreover, the vanity, and possibly sometimes the ignorance and errors, of succeeding judges which impelled them to improve upon the statements of their predecessors, have produced a great variety and conflict in rules. Even when the doctrine of stare decisis was thought to have been fastened on our system of law administration, these and other forces were present to break up the crystallization of any such fantastic attempt at law petrifaction. The efforts at statute making were designed to furnish a dependable ally in this process and they doubtless would have done so except for the constant tinkerings of succeeding legislatures, together with the habits of judges, by this time confirmed, to interpret and refine both upon the statutes as well as upon their own interpretations and refinements. But of even greater potency as an antidote to word worship has always been the loose language of

${ }^{13} 3$ Wigmore, Evidence (2d ed. 1923) §§ 1815, et seq., 2405, 2426; ThaYer, Preliminary Treatise on Evidence (1898) 24, 390; 1 Williston, Contracts (1920) § 205.

14 Professor Herman Oliphant gives a good instance: "A striking example of this is found in the fact that the legislature of Pennsylvania has enacted Professor Williston's draft of a uniform law, making any written release or promise valid and enforcible if the writing also contains an additional express statement that the signer intends to be legally bound." (1928) 14 A. B. A. J. 348. But see explanation by Professor Williston. Ibid. 554.

${ }^{15}$ Hohfeld's analysis is essentially such a scheme. Professor Kocourek's recent book, JuRAL RELATIONS (1927), is a most elaborate scheme of this sort. 
contemporary judges. So that with the facilities now at hand for writing, publication, and distribution of judicial essays on the cases adjudged by courts, together with the numerous adventures in legislation, the increasing range given to administrative officers outside the courts, the more perfected technic of lawyers in closing the ways that judges would make use of in their rationalizations if the ways were left open, as well as of opening new and unheard of ways, the infinite number of judges and book makers-with all of these, the fear of a language serfdom grows more and more remote. In fact, the fear of many is that we are swinging far beyond the point of safety the other way in allowing to judges what in effect amounts to "free decisions."16 This movement is sought to be halted by the subsidizing of a vast amalgamation of legal scholarship, reinforced by a far reaching political organization to make the work of the scholars acceptable. But even the efforts of an American Law Institute, as helpful to legal scholarship in particular, and to law administration in general, as it has already been and will continue to be, will prove fruitless in setting up a hierachy of rules and formulas. The day for that has gone. If such a movement should seem to succeed momentarily it is hardly to be expected that legislatures, judges and legal scholars will overcome the delightful habits of such long standing which impel them to seek changes in the order of things.

Under whatever guise it has been undertaken, the search for a language technic which would solve the difficulties of government has been the falsest hope of legal scholarship. No natural or social science has found its secrets in words and phrases and neither will the science of law. "Words are extremely imperfect tools and nobody has ever succeeded in mastering real things by means of mere words" says Ehrlich. ${ }^{17}$ There is no such thing as words so plain that they are not to be interpreted. There are no premises to be found so certain that nothing more than an irrefutable logic is required. The emptiness of multitudinous terms which have served as major premises of judicial logic has long been exposed. ${ }^{18}$ A process which assumes the very ends it is employed to discover will in the end betray its futility. It is not that a scientific language device is not desirable. It is merely that too much emphasis has been put upon it, and too much expected of it. The attempt has been made and still is made to make language do the service of judging itself. There can be no such substitution. Words are the machinery by which the power of thought is handled, but if there is no such power put into them the words are life-

${ }^{10}$ See Geny, Judicial Freedom of Decision; Its Necessity and Method, TнE Science of Legal Method (IX Modern Legal Philosophy Series, 1917) 15. Also Ehrlich, Judicial Freedom of Decision: Its Principles and Objects, ibid. 47, 69.

${ }^{17}$ Ibid. 70.

${ }^{18}$ See Cook, Scientific Method and the Law (1927) 13 A. B. A. J. 303. 
less. In the administration of law, both the judge who surrenders this power to phrases as well as the judge who spends his time attempting to pattern phrases to control succeeding judges in the cases to come, can only do his science ill. His function primarily is to pass an acceptable judgment in the case before him. When the next case arises a different judgment may be desirable. But both judge and legislator seem more deeply concerned for the future than for the present, as though the future would not have its own lawgivers. The institution of government is sustained by the life of the day as are other institutions. We can no more make use of the power that flowed through the words of Coke and Blackstone and Marshall than we can of the life contemporary with that power. We use their words, but their utility depends upon the power we ourselves generate. It could not be otherwise, nor is it to be regretted. As each day has its own problems, its own life to spend, it likewise will have its own language. Somehow or other thought has always found a way of articulating itself, and in a voice sufficient for the time and place. ${ }^{19}$ There is no warrant for the fear that a fluid language and adjustable rules are undependable. We have never had any other sort, although we have lost much by not recognizing that fact. The point is that we have looked to the wrong source for dependability. We have sought it through a technic of language instead of a technic of judging. We rather trust the machinery than its engineers.

\section{A Judging Technic}

Probably lawyers would more widely agree upon the suggestion that the judge is the most responsible unit in our social structure-that his judgment is the most vital factor of law administration-than upon

${ }^{10}$ Holmes, Rational Basis of Legal Institutions (1923) Introduction, p. xxx. "Any idea that has been in the world for twenty years and has not perished has become a platitude although it was a revelation twenty years ago. One might venture on the paradox that by the time a proposition becomes generally articulate it ceases to be true-because things change about as fast as they are realized." Wigmore, The Judicial Function, THE ScIENCE of Legal Method, op. cit. supra note 16, Preface p. xxvi, at p. xxxv: "If we recollect the differences of personality and community, and add to those the differences caused by lapse of time and change of environment, we shall realize that words are far from fixed things; they are the most fluent and indefinite of things."

Ehrlich, op. cit. supra note 16, 47, 61: "No theory of the application of law can get around the difficulty that every body of formulated rules is in its very nature incomplete; that it is really antiquated the very moment it has been formulated. Consequently, it can hardly govern the present and never the future. No such theory will ever be able to prevent the perpetual course of evolution of the social institutions to which the law is applied, whereby the formulated rules of decisions are constantly obliged to deal with new subject-matters. And it will also never be possible to avoid the fact that the individuals intrusted with the application of the law, being children of their nation and their age, will apply the law in the spirit of their nation and their age.... The most solid theories and the most powerful legislation must alike be shattered upon the rock of such realities." 
any other suggestion which could be made. About him must be built any program designed to serve a science of law. The difficulty has been to insist upon a red-blooded judge in one breath and in another insist that he be controlled by a bloodless theology. It is one thing to rely on the infallibility of rules and doctrines; it is another to trust the affairs of men to the fallibility of men's judgment. It has required a long process of painful experimenting to drive home the dreaded fact-if it be even now driven home-that men must rely upon the judgment of men and make the best of it. Says so intelligent a philosopher as Morris Cohen: "To be ruled by a judge is, to the extent that he is not bound by law, tyranny or despotism. It may often be intelligent and benevolent, but it is tyranny just the same."20 The eternal gropings of men to find a source of their own control beyond themselves will not down. Is there no way to control the exercise of that power we hand over to our judges save by rules of law? These are but the trappings through which judgment is passed. The most thoughtful of men stick at this point and here they turn back into the wilderness of words. But it is here than any rational administration of law must make its boldest step. It is here that the aids furnished by the multiple forms of legal terminology break down. The judging capacity requires not merely a clerk who can match phrases. Phrases can state the issue upon which judgment must be passed but they cannot pass the judgment. At this point the judge finds himself out in life at large beyond any bounds that the terminology of legal science yet knows and it is out here that the judge must find the power which sustains thought and judgment; it is out here that he must employ the processes of intelligent men generally. This hitching up of law with life is a gap that must be bridged before any mature science of law can be developed. A technic of judging finds its chief support in the depths of culture and experience which lie beyond the crusted phraseology of the opinions of judges. The control of judges is not to be found in rules, but in the fact that they are men nourished on the same thoughts and other life-giving forces as the rest of us, and are subject to be influenced by the same factors in making their judgments as those which influence their fellows generally. Judges, as other men, are bound by the factors which have conditioned their growth. ${ }^{21}$ These are the

${ }^{20}$ Cohen, Positivism and the Limits of Idealism in the Law (1927) 27 CoLUMBIA LAW REv. 237, 244-245.

${ }^{21}$ Kohler: "We overlooked completely that the lawmaker is the man of his time, thoroughly saturated with the thoughts of his time, thoroughly filled with the culture that surrounds him, that he works with the views and conceptions which are drawn from his sphere of culture, that he speaks with words that have a century of history behind them and whose meanings were fixed by the sociological process of a thousand years of linguistic development, and not through the personality of the individual." From Pound, Courts and Legislation, THE ScIEnCE of LEGAL METHOD, op. cit. supra note 16, 202, 224. 
very forces, which in turn determine the rules themselves that men utter. Could we but discover and articulate these factors we should know the limits of law itself.

Before such inquiry is made let the discussion take another turn. How do judges employ this power we call law? How do judges pass judgment? Has any one ever disclosed? It would seem that with the numberless judgments passed and the laborious efforts which judges have made to disclose the judgment-passing secret, there could be no mystery. But the processes of judgment are as obscure as the processes of thought. We think. (At least we say we do.) We judge. After we have judged we make use of all sorts of devices to indicate the lines our processes have followed in reaching judgment. We employ numberless mediums of expression. It is these that many minds grasp and fondle as though they themselves hid the secret of judging and by some process of devotion could be made to give up their secret. You have observed those who cling to the words of the judge as though they possessed some occult power to determine other judgments. And possibly they do have some such power for the occult judge. There is no gainsaying that the formulas in which judgments have been couched have been highly important factors in men's dealings. Along with other uses they serve as storage cells for a legal science. They range from the tiniest one-cell order to those of the highest multiples. But how are these formulas themselves produced? How are they charged with this power of law? We seldom go behind them; we begin with them. We have our rules, our doctrines, our rights, powers, privileges, immunities, duties, etc., but where did we get them, and why do we use them as we do? When we say in a particular case that plaintiff had a right, defendant was under a duty, and the like, this but means that we have already passed judgment. We are merely using these terms to pronounce the judgment passed. The process has been concluded in some unknown way; the result is merely being vocalized. We play around with our legal technic, make use of our robust phrases, as though they disclosed the secret of our judgment. But it is a rare thing that an opinion acknowledges the forces which must have impelled the judgment pronounced.

But I do not say that judgment is any less wise or dependable on account of this fact. It may be that the precision of the automaton is more to be risked than any attempt to handle factors far too numerous and elusive to be brought under conscious control. The conception of life may be instantaneous; the passing of judgment may only require an instant's focus. I do not know about this. But I am quite sure that as lawyers we constantly delude ourselves and likewise delude others by insisting that those delightful word jousts we call opinions are dependable 
guides to the workings of the judicial processes. When that stage is reached, the action has already been fought. An opinion is but the smoke which indicates the grade of mental explosive employed. Somewhere behind the curtains of legal expression lie the laboratories of our intelligence. They are not legal. They comprise all we are. Perhaps our judgments on the least item of the day are given shape there in the same way as our most solemn decision in a law suit. There lie our concentration centers as it were. There we do our work. A thousand flashes from all quarters answer our calls for power. Out of it all comes a judgment. Can we articulate these flashes. I hesitate to assert that we can, and even more so to make an attempt in that direction.

\section{The Judging and Language Technics in Negligence Cases.}

In the class of cases known as "negligence cases" a working analysis has been rather widely adopted which will serve our purposes here. Such a case has four elements: (1) the right-duty element; (2) the negligence element; (3) the damage element; and (4) the causal relation element. Ordinarily two judgment-passing agencies are employed in these casesthe judge and jury. The appellate court is left out of the picture as such, but of course it is a very important factor, and must be considered as a "part" of the "judge." Its function is primarily to say what the trial judge should have done. This dual tribunal requires an allocation of functions. And it is generally agreed that the problems arising under the right-duty element are for the judge, while the problems of negligence, damages and causal relation, if there is an issue raised as to them by the evidence, are for the jury under instructions. The writer has elsewhere dealt with the problems presented by the negligence and causal relation elements. ${ }^{22}$ The inquiry here is limited to the right-duty element. Here, if at all, we may expect to find crystallized rules upon which reliance can be placed.

The theology of the lawyer is not different from that of the saint. Nor can it be avoided; we can only hope for a better brand. The passing of judgment in bulk in such a complicated matter as a law suit is a dangerous thing. Our thought processes are not a vigorous lot. They cannot be trusted in emergencies. They have little daring. Their weakness makes them cling to the very shells of words. Note the sameness of an author's writings; the monotonous repetitions in a series of opinions by the same judge; the reproduction and glossing for a generation of the two or three best opinions on any subject. Hence, on account

${ }^{22}$ See my book, Rationale of Proximate Cause (1927) and my articles, $\rightarrow$ The Negligence Issue (1928) 37 Y $\mathrm{ALE}$ L. J. 1029; Contributory Negligence and Proximate Cause (1927) 6 N. C. L. REv. 3. 
of our weakness, we cultivate analysis and classification, logic and all of its processes, both as aids to judgment and to its articulation. However faulty these may be, we find them essential to our science.

Now it is clear that when the theology of a negligence case is swept aside all that is involved is that there must be a concurrence of judgment in plaintiff's favor both by judge and jury before a defendant is required to pay the loss. The machinery for obtaining this concurrence of judgment is most troublesome; it requires the analysis indicated above. The judge passes his judgment on so-called questions of lawrights and duties; the jury on so-called questions of fact-negligence, damage, and causal relation. The judge is the dominant factor in this arrangement. He not only passes his judgment first, but determines in what cases the jury can properly pass a judgment at all, ${ }^{23}$ as well as indicates some of the considerations which should be taken into account by the jury in passing judgment. The determination in a particular case of what problems shall be decided by judge and what by jury is not always easy. Here in this first preliminary judges make serious errors. It is frequently much easier to decide the case than it is to determine whether the jury shall have any part in its decision. In fact this dual arrangement is a most difficult one in practice-the least understood and most costly device of law administration.

In passing his own judgment, the judge may frame his problems in a variety of forms: (1) Was the defendant under a duty, and if so, was he under a duty to plaintiff? or (2) Was plaintiff's interest protected against defendant's conduct? or (3) Plaintiff having invoked some general rule, was such rule designed to give protection to plaintiff's interest? or (4) Was such rule designed to protect plaintiff's interest against such a risk as the defendant's conduct in the particular case? In another type of case it may take the form of whether defendant's conduct makes a prima facie case for plaintiff, or whether defendant's conduct was privileged or justifiable. But however framed, the issue is the same; the court must say whether there is any "law" which would require defendant to bear the risk or whether plaintiff must bear his own loss. Expressed more directly, the judge must decide whether

${ }^{23}$ Minturn, J., in Morril v. Morril, 142 Atl. 337, 339-340 (N. J. L. 1928) : "Hence it becomes imperative before legal liability for conceded damages can be imposed upon a defendant, for the court in the first instance to inquire and determine the character of duty which the law under the facts imposed upon the defendant as the basis of liability; for manifestly it cannot be conceded that the jury from their inner consciousness may evolve in every variety of tortfeasance a legal duty as the standard of liability. The rule of legal duty or the standard of human conduct under any given circumstances must be declared by the court as a preliminary to the submission of the case to the jury, and, if upon the conceded facts no rule of legal duty can be said to have been transgressed, legal liability cannot be said to supervene so as to warrant the submission of the case to the jury." See Meyer v. Benton, 74 N. J. L. 533, 65 Atl. 1023 (1907). 
he would be willing to see the risk placed on defendant even though the jury should find affirmatively on this question. All of this assumes, of course, that the jury's judgment is yet to be passed, and that such judgment may or may not concur in any phase of the matter left to the jury. Assuming it is not a pattern case how does the judge know whether there is any such "law"? How does he know how to pass judgment? How does he know what protection to give to plaintiff's interest? Inasmuch as this inquiry has come to be normally expressed in terms of "duties," let us think of this problem in these terms. Was the defendant under a duty to plaintiff? We shall be fortunate if we do not lose our direction at the outset even in this small run-way of words.

How does the stating of the problem in terms of duties enable a judge to pass judgment? Where shall he find the source of duties? Do judges find them ready made? Do they assume them? Do they create them, and if so, do they create them in wholesale, or must each court create a particular duty which fits the particular case then before it? So far as I have been able to discover, the common law courts have stumbled through the whole period of their existence without committing themselves on this inquiry. Perhaps it is a subject which is not to be talked about. We are clearly dealing with the very processes by which law is generated. And doubtless the questions as to the paternity of these duties brought forth in case after case is embarrassing enough at best.

It would be as futile to attempt to state for the judge the limits of the law's protection in advance of the particular conduct, as it would be to state for the jury the sort of conduct they should condemn. Conduct is infinite in its variety. The most a legal science can do with the classes of cases here involved is to employ broad formulas both for judge and jury and rely upon their respective judgment-passing capacity to dispose of the cases satisfactorily as they arise. ${ }^{24}$ But judges are slow

${ }^{24}$ See discussion on this point in my article, The Negligence Issue, supra note 22. Dean Pound's observation with reference to legislation is equally applicable: "It is a lesson of all legal history that the most we may achieve in advance is to lay down a premise or a guiding principle and that the details of application must be the product of judicial experiment and judicial experience." Pound, op. cit. supra note $21,227$.

Judge Cardozo gives the proper dimensions: "The endless variety of the process is indeed a source of never-ceasing wonder. One would suppose after all these centuries of judging that the frontier would have vanished, that there would no longer be unsettled soil, no longer nebulae and star dust, but only peopled worlds. Yet in truth it is not so. There are topics where the law is still unformed and void. . . . I am struck by this from day to day in the course of my judicial work. I am struck by it again when following the work of the American Law Institute in the restatement of the law. One cannot have a part, however humble, in the execution of that project without a mounting sense of wonder that with all our centuries of common law development, with all our multitudinous courts and still more multitudinous decisions, there are so many questions, elementary in the sense of being primary and basic, that remain unsettled even now.... I have noticed this particularly in connection with the law of torts. . ." Cardozo, ThE ParADOXES OF LEGAL SCIENCE (1928) 76, 77. 
to confess even to themselves that the administration of law rests on so uncertain a foundation. We are eager to believe that this is a "government of laws and not of men." We are pained when we come face to face with the fact that there is nothing more stable in our civilization than the common fund of desires, habits and intelligence of ourselves and our neighbors. And we refuse to believe that the power of passing society's judgment on the every-day affairs of society can be safely intrusted to the men whom we select as judges.

Duties are usually stated in broad terms. In negligence cases thistakes the form of the "duty to use reasonable care." This means little. Even when it is said that a person owes a "duty to use reasonable care (for example) towards other travellers on the highway," or "duty to provide a reasonably safe place for a servant to work," and the like, these are little more than pious aphorisms. Nothing more has been stated than that some interests of travellers on the highway and some interests of a servant are given protection by organized society-government. But what interests and how much protection, or what specifically is required of respective defendants, are in no way indicated. Something is still lacking. We must say that plaintiff's interest in his bodily integrity or in his vehicle as a traveller on the highway is protected against defendant's conduct in driving too fast, or failing to give or obey traffic signals, or driving a car without good brakes, etc., before we have stated a graspable proposition. In other words, we must say that defendant is under a duty to plaintiff to drive at a reasonable speed, give or obey signals, have good brakes, etc. And even here the pattern is barely suggested; the cloth is still uncut. We have not yet stated that a particular plaintiff has protection against a particular defendant's conduct, or that a particular defendant owes a particular plaintiff any specific duty. And what is more remarkable, we can never say these things, save in the rarest cases, prior to the time the conduct to be passed upon has transpired and is presented in an actual case in court. Aside from those few cases where duties have been stated in terms of conduct, the duty a defendant was under, or the protection a plaintiff was entitled to have, is unknowable until the case has been adjudged. And it is here that we ask, how are these duties of defendants ascertained? And how are they to be stated until they are ascertained?

The general duties stated in terms of "reasonable care" and similar abstractions are not difficult to state, but when they are so stated they go very little distance in giving aid to the judge in the particular case. The judge very quickly arrives at the point where he must say whether the generalization is applicable to the particular case; whether plaintiff is entitled to any protection under it; whether defendant was under any duty with respect to the conduct that transpired, and the interest 
which was injured. How can a judge know this? How can a judge say there was a duty in this case and not in that one? This is the first problem in any case. In the "mine run" of cases it may not be so very difficult because other more or less similar cases have blazed trails. But how did it happen that the trails were so blazed? The countless varieties of conduct make this problem constantly fresh. Let it be said again that this is the dimmest part of tort law, perhaps of all law. It presents the hardest problems in any field. It is the most important; it is the one at which judges quail; it is the one which is most frequently hidden in a mysticism of words.

\section{The Test of Duty}

Here there is frequent resort to those numerous "tests" of duties which have been evolved for various types of cases. ${ }^{25}$ For the most part these have been devised for the judge's own aid, though in some instances, judges have cleverly deceived themselves into believing that by certain devices they can get assistance from juries at this point, and some of these devices are the merest rules of thumb, or possibly even smoke screens for the particular case. Certainly there is no censure for a particular judge's "grabbing at straws" when there has been no serious attempt to formulate rational bases of judgment at this point.

1. Affirmative conduct. The most definite boundary of negligence law is the line between affirmative and negative conduct. ${ }^{26}$ Broadly

${ }^{25}$ These tests are found in many cases and are phrased in all sorts of fashions. A few of them are indicated here: SPENCER, Formula of JUSTICE (1891) § 27 : "Every man is free to do that which he wills, provided he infringes not the equal freedom of any other man." 1 CoMYNS DIGEST (1780) 128: "In all cases, where a man has a temporal loss, or damage by the wrong of another, he may have an action upon the case to be repaired in damages." Wolf v. Des Moines Elevator Co., 126 Iowa 659, 664, 98 N. W. 301, 302 (1905): "No man shall make use of his own property in such manner as to unreasonably interfere with the enjoyment on the part of others of the rights conferred upon them by law." This generalization is stated in numerous ways. One of the most interesting is found in Barger v. Barringer, 151 N. C. 433, 440, 66 S. E. 439, 442 (1909): "The ancient maxim of the common law, Sic utere tuo ut alienum non laedas, is not founded in any human statute, but in that sentiment expressed by $\mathrm{Him}$ who taught good will toward men and said, 'Love thy neighbor as thyself.' Freely translated, it enjoins that every person, in the use of his own property, should avoid injury to his neighbor as much as possible."

${ }^{26} \mathrm{~S} \rightarrow$ Bohlen, The Basis of Affirmative Obligations in the Law of Torts (1905) 53 A m. L. Reg. 209, 237, 377; Studies in the Law of ToRTs (1926) 33. "It is surprising to find that every attempt to announce either judicially or in textbooks any inclusive affirmative principle of the origin of the duty of care, the primary fundamental requisite, has been unsuccessful." Ibid. pp. 209 and 33 respectively.

"There is no distinction more deeply rooted in the common law and more fundamental than that between misfeasance and non-feasance, between active misconduct working positive injury to others and passive inaction, a failure to take positive steps to benefit others, or to protect them from harm not created by any wrongful act of the defendan $\rightarrow$ Bohlen, Moral Duty to Aid Others as a Basis of Tort Liability (1908) 56 U. of PA. L. Rev. 217, 219, 316; Studies in the LAw oF TORTs 291, 294. 
speaking no person is under a duty to another unless he has entered upon some course of conduct towards such other. As long as a person does nothing he comes under no duty imposed by law. This is one of the most dependable limitations upon duties, but it is a limitation seldom required to be made. Probably after all we are merely saying that in the tort field at least this power we call law is merely designed to control conduct and not to compel it. We have enough to do to keep our activities within control, without attempting to regulate the directions the latent energies of individuals should take. But the line of affirmative conduct has not always been easy to draw. ${ }^{27}$ By taking a view at too close range courts have sometimes reached results wholly out of line with the views of society at large. Take for instance the case in which defendant runs into plaintiff with an automobile or train and seriously hurts him without the violation of any duty to plaintiff. Does defendant then owe plaintiff a duty to stop and render assistance? Courts have held not. ${ }^{28}$ But it ought to be clear that a defendant in such case is not in the position of one who had merely done nothing as in the case of a defendant who stands by and sees a baby run over or a blind man walk off a cliff when defendant could rescue either without danger to himself. On the contrary, the defendant has affirmatively hurt the plaintiff and in so far as affirmative conduct is concerned, defendant is well inside the lines. He may well not have violated any duty to plaintiff in hurting him, but the fact remains that he did hurt plaintiff. Now the question is entirely different. Having hurt plaintiff should the law impose a duty upon defendant to take further steps to render aid to his victim ?29 Why should it? Why should it not? The assumptions made by the courts generally preclude this most important question.

Likewise it has been assumed that a landowner for some reason is beyond the line of affirmative conduct with reference to those who come on his land and into contact with the dangerous instrumentalities which he employs there. In other words, it has been assumed with reference to the use of his land that the landowner is not subject to the duties which another person incurs by using his chattels. In most jurisdictions

${ }^{27}$ See Bohlen, The Moral Duty to Aid Others as a Basis of Tort Liability, supra note 26. For citation of authorities see (1928) 12 Minn. L. Rev. 765.

${ }^{28}$ Union Pac. Ry. v. Cappier, 66 Kan. 649, 72 Pac. 281 (1903); Note (1903) 69 L. R. A. 513. See recent case of Osterlind v. Hill, 160 N. E. 301 (Mass. 1928).

${ }^{20}$ See Ames' suggestion, Law and Morals (1908) 22 HARv. L. Rev. 97; SELeCted Essays on the Law of ToRTs (1924) 17. Also Bohlen's argument in his book, Studies in the Law of Torts (1926) 339. Numerous statutes now require a motorist who has a collision with another person to stop, give information disclosing identity, etc., and to render aid if the other person's condition requires it. The common law courts seem to have been frightened away at this point for fear they would be invading the precincts of morals, as if legal protection is not to be influenced by moral considerations. 
the assumption has been repudiated as to young children. Why were duties not always imposed on landowners in these cases? But of equal importance why do some courts now impose such duties ?30 Whatever the reasons may be for not imposing responsibility in these cases it is not because such landowners are without the lines of affirmative conduct.

2. The "danger" test. But the line between affirmative and passive conduct being conceded as a possible one, when will duties be imposed upon affirmative conduct and to what extent? After all, this is the heart of the inquiry.

Brett, M. R., in Heaven v. Pender made the most impressive attempt to answer this puzzling question. His formula runs like this: "Whenever one person is by circumstances placed in such a position with regard to another that every one of ordinary sense who did think would at once recognize that if he did not use ordinary care and skill in his own conduct with regard to those circumstances he would cause danger or injury to the person or property of the other, a duty arises to use ordinary care and skill to avoid such danger."31 His brothers on the bench would have none of his generalization. Brett, himself, repudiated it when attempted to be used in other than personal injury cases.32 But even though the rankest dictum, it has sufficed as a rationalization of duties in hundreds of cases. It has come to be known as the "danger" test of duty. Whenever defendant's conduct threatens danger there is a duty to take care. It thus would seem to serve as an adjustable test ready for all purposes.

${ }^{30}$ For a long time the "Turntable" or "Attractive Nuisance" doctrine was thought to be anomalous. Although many courts recognized it in some form it was placed on the most fantastic grounds. So able a writer as Jeremiah Smith vigorously opposed the doctrin $\rightarrow$ Smith, Liability of Landowners to Children Entering Without Permission (1898) 11 Harv. L. Rev. 349, 434; Selected Essays ON THE LAW OF TORTS (1924) 357. In recent years the doctrine has become well established in most jurisdictions. $\rightarrow$ Hudson, The Turntable Cases in the Federal Courts (1923) 36 Harv. L. Rev. 826; Selected Essays on the Law of Torts (1924) $3 ! \rightarrow$ Green, Landowner $v$. Intruder: Intruder $v$. Landowner-Basis of $R e-$ sponsibility in Tort (1923) 21 MICH. L. Rev. 495. Both writers agree, and find some support in the cases, that the landowner as any other person is to be governed by the usual requirements to exercise ordinary care in the use of his property. This was assumed as the basis of the very first case, Sioux City \& Pac. R. R. v. Stout, 17 Wall. 657 (U. S. 1873). But the courts have given practically no grounds as to why this should be so. Although the doctrine is sound it cannot yet be said to have struck bottom. Notice how one of the better recent cases glides over the troublesome point. Clark v. Longview Pub. Service Co., 255 Pac. 380 (Wash. 1927); (1928) 28 Columbia Law Rev. 249. Even so able a judge as Justice Holmes seems unable to reach the heart of the problem. United Zinc \& Chemical Co. v. Britt, 258 U. S. 268, 42 Sup. Ct. 299 (1922). Judged by the opinions, there are few situations where the emotions seem to have played so large a part, and where an appraisal of the factors and interests involved has been given so small a part.

${ }^{31} 11$ Q. B. D. 503 (1883).

${ }^{32}$ Le Lievre v. Gould,. [1893] 1 Q. B. 491. 
Here is probably the strangest chapter in all tort law. Upon analysis it is clear that this formula is identical with the "foreseeability" or "anticipation of harm" formula. In fact, it is nothing more than the foreseeability test of "negligence," which, when spelled out, depends upon the utility of the "man of ordinary prudence" as a standard of measurement. ${ }^{33}$ These are the test and standard by which juries determine the negligence issue, i.e., the violation of duty. Now it would be passing strange if (1) the delimination of the law's protection, duty vel non, is to be passed over to the jury. That would end any possible hope of law crystallization; there can be no such thing as statement or restatement of the law where the jury must pass judgment; the very purpose of jury trial is to give a new deal in each case. But (2) it would be stranger still if the law should provide the judge with the same formula for use in determining the existence of duty as it gives to the jury for the determination of the violation of duty. Yet to all appearances this is exactly what has taken place. Incidentally, the very same test is repeatedly insisted on as the test of causal relation also. ${ }^{34}$ Thus it would seem that analysis has played itself false, so that a case is seemingly to be subjected thrice to the ponderous process of the "foreseeability" formula.

But fortunately no such thing is true, nor can it be true. Courts sometimes say that in hard cases they call in the jury to determine this duty problem..$^{35}$ They may think so, but doubtless they do nothing more than let the matter go by default. It happens in this wise: By virtue of the fact that the judge is the dominant factor of the dual tribunal set up for these cases, the moment a case is passed to the jury, that moment

ss "The man of ordinary prudence" as an attempted objectification of a standard for determining the reasonableness of conduct based upon foreseeability, probable consequences, anticipation of harm, probability of harm, danger, etc., is fully discussed in my article, The Negligence Issue, supra note 22 . See Bohlen's analysis, The Probable or the Natural Consequence as the Test of Liability in. Negligence (1901) 40 AM. L. REG. (N.s.) 79, 86; also op. cit. supra note 29, 1, 9: "To constitute actionable negligence there must be: (1) A duty to the plaintiff to observe care. This depends upon the probability of injury if care be not taken. (2) A standard of care not observed (constituting the breach). This again depends upon the anticipation of probable danger. .. " The confusing of the two problems, duty and violation of duty (the judge's function with the jury's function) is believed to be very hurtful. The writer for a long time accepted the same view. See my article, Are Negligence and Proximate Cause Determinable by the Same Test (1923) 1 Tex. L. REv. 242, 256.

34 Ibid. 243; Green, Rationale of Proximate Cause (1927) 177.

${ }^{35}$ See Bird v. St. Paul \& Marine Fire Ins. Co., 224 N. Y. 47,120 N. E. 86 (1918). Also see Holmes, The Common Law (1881) 123; Collected Legal PAPERS (1921) 233-234. These eminent legal scholars are not discussing the defining of duties in so many words, but they are dealing with the problems involved in marking the limitations on legal protection in difficult situations. Their suggestions fall short of the whole story and perhaps are frequently taken to mean something different from what was intended. The adjustment is not an easy one to make clear. 
the judge necessarily has ruled that there is a duty upon the defendant, who will be held responsible if the jury concurs in the case as presented to them. The jury's problem is ordinarily submitted at length under some variation of Brett's formula. In submitting this problem, the judge may think that he is shifting the whole burden to the jury. But he is not. $\mathrm{He}$ is at most merely allowing the case to be decided on the jury's problem without meeting his own squarely. But, of course, this very failure on his part necessarily operates as a ruling that there is a duty or else he never would have submitted the case to the jury at all. In other words, the judge passes on the existence of duty any way he may rule. If he consciously says there is no duty he will direct a verdict for defendant. If he consciously holds there is a duty he will submit the case to the jury on the negligence and other issues if there is any evidence raising them. But even though he tries to pass the question of duty to the jury, he cannot do so. The very passing automatically means that he has adjudged a duty to have obtained, and nothing but the jury's concurrence as to its violation is required in order to place responsibility on defendant. No other analysis of the respective functions of judge and jury will suffice, unless it be conceded that the jury alone has the power of determining the limits of protection which government is to give the interests of litigants. This would give to juries the power to fashion law in the most difficult cases. It would be a surrender of the highest power of the judicial process to the lay members of the court. It would render any statement of the rules of law impossible. But the answer is short-no such practice is recognized. When it comes to the pinch, whatever they may say, judges do not surrender this power. They may do curious things but this is not one of them. When a judge throws a question of this sort to a jury it is because he is willing to say that in his judgment plaintiff's interest should be protected, and defendant must pay the damage if the jury think his conduct violative of the standards which are recognized in such cases.

The whole confusion comes about by the legal theology which requires substituting a symbolic phrase "determination of duty" for the judgment required of a judge in giving or denying the protection of government to the interest involved, and a like substitution of the figure of speech "violation of duty" for the jury's judgment giving or denying such protection. Thus our terminology gets in the way. In the cases which the judge thinks are clear he relies on his judgment alone at this point, but if he thinks the matter doubtful, our theory of the judicial process in tort cases requires the concurrence of the jury. But the jury's power is that of a concurrence or veto only. The jury's power is only exclusive in ascertaining the truth or falsity of the eviden- 
tiary data relied on to sustain the claim. Here it may be that juries often exercise a far greater power than they should, due to the difficulties of separating their functions under a general verdict. But this is a perversion of power similar in all things to a judge's misuse of his power in holding a doubtful case to be a clear one involving no question for the jury. His functions of saying (1) there is no evidence to go to a jury and (2) that even though there is evidence, the law clearly gives no protection in such a case, allow the widest exercise of the judicial power. Good sense and the political powers of government are the only checks against its abuse.

Nevertheless, the "danger" test of duty has great currency. In MacPherson v. Buick Motor Co., ${ }^{36}$ Cardozo, J., accepted Brett's generalization as a principle by which to hold the manufacturer of automobiles to the duty to inspect in behalf of the ultimate user of the automobile. "Because the danger is to be foreseen there is a duty to avoid the injury," he said. In Glanzer v. Shepard ${ }^{37}$ the same great judge uses the same test of duty in order to hold a public weigher employed by the seller responsible to the buyer for a shortage in weight of beans. $\mathrm{He}$ thus extended the generalization to cover a class of injuries which Brett himself had refused to include on the ground that the rule was to be restricted to personal injuries. ${ }^{38}$ Very recently he has again phrased the rule: "The risk reasonably to be perceived defines the duty to be obeyed, and risk imports relation; it is risk to another or to others within the range of apprehension." 39 After a wide survey of the cases the Torts Restatement group of the American Law Institute have accepted this test, and it would seem therefore an accepted major premise of "negligence" law. ${ }^{40}$

It is with great deference and hesitance that I suggest the inaptness of any such test, however heartily I agree with the results reached in the cases mentioned and other cases like them. It seems entirely too misleading, and this, even as a shorthand expression under which to subsume the numerous factors which impel judgment. To eliminate dangers and hurts is, of course, one of the chief ends of law; such is the prime purpose of tort law. But the use of so wide a variable as this as a part of a language technic, either for clarifying the issues for judgment or

${ }^{36} 217$ N. Y. 382, 111 N. E. 1050 (1916). The large part which the idea of danger plays in this opinion can only be appreciated by reading it.

${ }_{37} 233$ N. Y. 236, 135 N. E. 275 (1922). Many types of cases are catalogued in this excellent opinion as giving support to the same basis of duty.

${ }^{38}$ Le Lievre v. Gould, supra note 32.

${ }^{30}$ Palsgraf v. Long Island R. R., 162 N. E. 99 (N. Y. 1928).

${ }^{10}$ See Torts Restatement, Preliminary Draft No. 20 (Am. L. Inst. 1928) $\S 166$. Here the phrase "unreasonable risk" is substituted for "dangerous conduct" and similar phrases. See a $\rightarrow$ Seavey, Negligence-Subjective or Objective (1927) 41 Harv. L. Rev. 1. 
for rationalizing judgment after it is passed, seems inapt to say the least. It is well enough to use this test as a formula to pass the case to the jury for their judgment. There it is ritual. It serves well as a graphic method of stimulating the layman's consideration. He can pass his judgment as well under it as any other formula. But in calling for the judge's judgment in defining duties, why should that judgment be restricted by any such formula? There are numerous factors on which the mind of the judge must be focused before he can declare this judgment, and such a formula would seem designed to obscure them by too great a vividness concentrated upon one factor only.

No doubt the great emphasis which is given to the "danger" concept is because it graphically brings into play the factor of "experience," the greatest factor in all judgments, whether by lay or law judges. While great store has always been laid by experience, society has never given itself over to it entirely. Experience is too conservative, while society constantly calls for experiment and growth. Experience means in large part imitation, and life refuses to subject itself to imitation in all things. ${ }^{41}$ Courts have not as a matter of fact been controlled by the prospect of danger. On the other hand, they are constantly putting approval on conduct despite its dangers. Other factors are more compelling. Judge Cardozo himself is one of the first to recognize this fact. In his recent Carpentier Lectures he says:

"We build skyscrapers, though smaller dwellings might be safer for the builders. We run railroads, though lives might be saved if we were satisfied to travel slowly. We experiment with airplanes, though pilots run the risk of death. ... The law will not prevent the erection of skyscrapers. It may call for safety devices that will reduce the toll of lives. The law will not prevent the operation of railroads. It may call for signals and watchmen, and may raise or depress the roadbed at the crossing of a highway." ${ }^{22}$

He might have added much more. We give to the users of automobiles all the protection given to other persons, in the face of steadily increasing losses of life and limb. ${ }^{43} \mathrm{We}$ employ explosives, give our chemists and other scientists the widest latitude in their experiments, even though human life must pay the bill. In brief the law of negligence

${ }^{41}$ Allen, Law in the MaKing (1927) 59-68.

${ }^{42}$ Cardozo, op. cit. supra note $24,57,59$.

${ }^{43}$ Over a seven year period from Jan. 1, 1919 to Dec. 31, 1927, 137,017 persons were killed by automobiles in the United States, and during the same period approximately 3,500,000 injured by the same source. See Lattin, Vicarious Liability and the Family Automobile (1928) 26 MICH. L. REv. 846, 866. But in face of such facts the automobile is not outlawed. Courts merely invent a "family purpose" doctrine, extend a "negligence per se doctrine" and similar devices, while the legislatures require examination for licenses, registration of cars, compulsory insurance, and the like. Danger has never stopped a useful invention. 
could very properly be called the law of the dangerous machine. Surely if danger were now made the test of duties, our activities would be speedily curtailed.

In the same case in which the user of an automobile was allowed to recover from the manufacturer because of personal injuries caused by a defective wheel, ${ }^{44}$ the same court would have denied recovery for the injury to the automobile itself, though it was a hundred times more "foreseeable" that there would be hurt to it and consequently to plaintiff's pocket-book, than that his person would be hurt. ${ }^{45}$ The same court would not defeat a person who rushed in front of a speeding train to save a child, ${ }^{46}$ or walked a dangerous trestle to aid a comrade. ${ }^{47}$ The same able judge says in such a case: "Danger invites rescue. The cry of distress is the summons to relief. The law does not ignore these reactions of the mind . . . . The emergency begets the man." ${ }^{8}$ Courts applaud here as does all mankind. Danger we should like to eliminate, but not at too great a price. The factors which control the judgment of judges in placing the risks first upon one party and then upon another in the growing variety of cases which the activities of men are constantly presenting to courts must be found elsewhere.

3. Suggested determinants of duty. What are these factors which control judgment in defining duties? We can scarcely defer a conclusion longer.

It would seem that the process of identifying and delineating those factors is a first requisite in any serious effort to deal with the administration of this power to judge through which we seek to control our affairs. And that they do not differ in any great degree from those which control the like power of judgment in other affairs which we normally think of as outside the scope of government is constantly becoming clearer. In short, the concept of law is defined by the limits of governmental activity merely for the sake of convenience. The usages, customs and mores in all realms of society, from the least obligatory to the most obligatory (short of the stage when they are given cognizance in the judgments of courts, but which may be equally constraining in their respective realms) are doubtless controlled by the same factors as the judgments we call law judgments. The term law is merely a term which is most generally used to indicate governmental control, as opposed to other sorts of control. But law, as power to subject people to control

${ }^{44}$ Supra note 36.

${ }^{45} 1$ Williston, Sales (2d ed. 1923) § 244 ; Windram Mfg. Co. v. Boston Blocking Co., 239 Mass. 123, 131 N. E. 454 (1921).

${ }^{46}$ Eckert v. Long Island R. R., 43 N. Y. 502 (1871).

${ }^{47}$ Wagner v. International Ry., 232 N. Y. 176, 133 N. E. 437 (1921).

${ }^{48}$ Ibid. 
by passing judgment, is no different in government from what it is in church, in fashion, in that mass of every day relations which prevail throughout human society. The disputes about the nature of law and the attempts to differentiate it from usage and custom ${ }^{49}$ would seem to be of little avail. What is the end to be served? Law as an instrument of formal government is understandable. Law as a means for use by a church or other organization is understandable. Law as existing in customs, usages and mores which more formal government takes for granted, is understandable. But it is one and the same power wherever found, indivisible and ungraspable. The difficulty is not with the nature of this power. The difficulty comes in our attempt to draw distinctions in units of power, when all that we mean is the difference in the uses made of that power. Hence, my suggestion is that law, wherever found, is in turn controlled by factors largely common to all sorts of administration, whether of formal government or other forms of group activity. I realize that to name these factors is to encourage disputes as to the proper terminology. That cannot be avoided and I would not avoid it, for the factors are not objective and neither are the meanings of words. What will mean most to one, will mean least to another. There is neither hope nor need for a standardized terminology which will suffice for longer than the hour. The life of expression is no different from life in other forms. Usage, of course, is the means through which both words and classification grow, and develop symmetry; likewise it is the way of their death.

The following are believed to be the factors of most significance in influencing the determination of duties and through them the limits of the protection afforded by law. There are doubtless others:

1. The administrative factor.

2. The ethical or moral factor.

3. The economic factor.

4. The prophylactic factor.

5. The justice factor.

Each of these must be satisfied somewhat in every acceptable decision. No judgment can long prove acceptable which develops very great pressure at any one of these points. No one can be overstressed, though now one and then the other will seem to be dominant. If a human desire or interest cannot be given protection without offending one or more of what might be called the "social senses" corresponding to these several factors, then it must go without protection; there is no duty to respect it. These "senses" as developed in judges and through

\footnotetext{
${ }^{40}$ See Allen, Law rn the Making (1927) cc. 1 and 11.
} 
the judicial process are therefore of the greatest importance. Their influence can be demonstrated in hundreds of cases.

\section{The Administrative Factor}

When it is sought to discover to what extent the purely pragmatic difficulties of operating our ponderous legal machinery affect the results, the inquiry proves baffling. Only the more important considerations can be given attention here. In the first place, there is nothing so weighty with court-room government as the workability of a rule or a process. If a court is asked to extend its protection to a new interest or against an unusual hazard which threatens a well established interest, it will not do so if its attempt would appear to be unduly burdensome, expensive or vain. A court will not knowingly enter upon a course of dealing which it cannot finish, or that may bring down upon it an increase in business or a mass of problems which it is not prepared to handle. On the other hand, even though a rule or practice has become antiquated and no longer meets the requirements of business, ethics, or justice, if it works easily and judges understand its operation, they will hesitate to discard it for some improved practice not yet accepted generally, even though the latter promises much greater utility. The caution of courts is due primarily to this influence rather than to that overstressed and purely theological notion represented by stare decisis. Or, stated differently, the doctrine of precedent is weighty, not so much because courts either dislike improvement or feel themselves bound by prior decisions, but because changes require all sorts of adjustments that cannot be anticipated. The troubles are not limited to the single case. This in part explains why legislation creates so much trouble for courts and why they have always found so many ways of discounting it. Each court invariably sets up its own scheme of things. ${ }^{50}$ It takes many years to extend this scheme of things to cover even the most im-

\footnotetext{
${ }^{50}$ Here we must think of a court as the judiciary of a single jurisdiction. By the phrase, "scheme of things," I mean the sum of the methods which a court employs in handling its business. It develops all sorts of doctrínes and practices which make the "local law" of any state of extreme importance. One court will not recognize the "last clear chance" or the "negligence per se" doctrines, for instance, but will get all the results of such rules by some other doctrines. One court will have nothing to do with mandamus and certiorari except in the most restricted respect, while another court will promote their use as methods of review in important cases which cannot await the ordinary processes of appeal. One court will repudiate the third party beneficiary doctrine and get the same results through some theory of trusts. One court will adopt a theory of absolute ownership of oil and gas and spend years aligning its real property rules in accord therewith; another will adopt a no-ownership theory and align its property rules in accord therewith. There are literally hundreds of these variations which in the aggregate constitute a court's methods, and every court has them in abundance.
} 
portant groups of problems which come before it. In the meantime all sorts of changes are taking place in the world outside. Any considerable change in the court's "scheme" may require a re-examination and realignment of many doctrines, a process which cannot be completed for years. It is little wonder that opposition is encountered when the integrity of the court's scheme of things is threatened by some new doctrine or new practice, or new demand for relief. It was as a defense for use in this sort of predicament that the doctrine of stare decisis became established late in the nineteenth century as applicable to substantive law principles. The short-sighted philosophy that thought government could be operated precisely by rules and doctrines and principles reached its maturity at that time, and judges, reflecting this general idea, sought by the means of the doctrine of stare decisis to crystallize them. ${ }^{51}$ This doctrine has never been needed, it can be obviated in any case, but it is sometimes embarrassing and frequently requires subtlety in order to avoid its effects. ${ }^{52}$ It creates infinitely more difficulties than it renders benefits. ${ }^{53}$ For one thing a court's scheme of things may become so

${ }^{51}$ Allen, op. cit. supra note 49, 123-146, gives a most interesting development of the doctrine of precedent. Strangely enough during its formative period the doctrine was confined to procedural matters (ibid. 143-144). As late as 1833, Parke, J., in Mirehouse v. Rennell, $1 \mathrm{Cl}$. \& Finn 527, 546, spoke of the doctrine merely as a "principle of decision" to be kept "steadily in view" (ibid. 145). See also Pollock, First Book of Jurisprudence (4th ed. 1918) 323 et seq.

${ }_{52}$ Allen, op. cit. supra note 49, 148. Among other rules for interpreting precedents he says, "It is for the court, of whatever degree, which is called upon to consider the precedent, to determine what the true ratio decidendi was." The ratio decidendi is all that is authoritative.

${ }^{53}$ Ibid. c. IV, 147 . This chapter indicates the authority and operation of the doctrine. Note the elegant theological superstructure implied by the following gems from this chapter:

"Let us remind ourselves of Sir George Jessel's simple principle, that precedents are employed in order to establish principles. Throughout the whole application of the law, the principles are primary and the precedents are secondary, and if we lose sight of this fact, the precedent becomes a bad master instead of a good servant. The business of a court in deciding any particular issue is to work its way by the inductive principle, which I have mentioned, to a rule" (ibid. 159). Quare: Why be so anxious about finding "principle"? But having found it why bother further with stare decisis?

"The difference between authoritative and unauthoritative precept is only the difference between what is logically relevant and what is not. For underneath the whole elaborate structure of precedents in our courts lies a permanent foundation of fundamental legal doctrine. "It is a dangerous thing," says Coke, "to alter or shake any of the fundamental rules of the common law, which in truth are the main pillars and supporters of the fabrick of the commonwealth" (ibid. 164).

"We say that he is 'bound' by the decisions of higher courts. But he is bound only at his own discretion, according to his own judgment. Nothing can make the process of 'binding' merely automatic and mechanical, for the judge has first to decide, according to his lights, whether the illustration is really opposite to the principle he is seeking. The humblest judicial officer can disregard the most authoritative declaration of the House of Lords unless he considers that the precedent cited is 'on all fours.' It is therefore fallacious to regard the application of precedents in the courts as a mere functioning of machinery. It is 
ponderous in the course of time that the succeeding judges cannot possibly know what their predecessors have done. Courts unwittingly reverse themselves more often than otherwise, and doubtless they spend more time trying to maintain a consistency of decision than on any other one problem. Moreover, this feeling that a court must drag along the dead part of itself creates a psychological deadweight of tremendous import.

Another phase of this matter enters here. The political organization of our court systems into inferior and superior branches works heavily against change and strongly for a status quo. The trial judge is the most important officer of government. There is no statesmanship so valuable as that of the trial judge who has the capacity for doing business without making that an end in itself. Government can pay too high a price for administration and citizens have always been afraid of judges who turn their power too decidedly to efficient business methods. Yet, poor trial judges furnish the business in large part for the appellate courts. Nevertheless, our court systems tend more and more to magnify the appellate judge and to belittle the trial judge. The latter ought to be the ablest and best trained man in the judiciary. But let a trial judge show evidences of capacity and shortly he will be elevated to the appellate bench, where he is of less value, although his burdens will be made easier and his income greater. The objectives of the two courts quickly diverge. The trial court is absorbed in law administration at first hand. The appellate court is so far removed from the real controversy that it more and more becomes concerned primarily with fashioning harmonious rules and doctrines for use by trial courts. This divergence is inescapable. A theory of law which finds its roots in words and rules must necessarily have a court of final jurisdiction to interpret words and construe rules. This in turn necessitates a theology of precedent, and it also accounts for the fact that a fair adjustment of the particular case must be sacrificed, if need be, to the consistency of a legal doctrine. It is not at all remarkable, therefore, that in the final analysis, to lawyers in general, legal dogmas are dearer than either a just, ethical or pragmatic administration of law. It is worthy of note that the stare decisis doctrine did not mature until the maturity of the appellate court in its present day form. It is very clear that nothing less than a radical struca complex process, depending greatly. upon the faculties of individual judges" (ibid. 164).

"If it is true that precedents are employed only to discover principles, so it is true that principles are imployed only to discover justice. ... This dominant purpose all precedents, all arguments, and all principles must subserve and when precedents do not help, enlightenment must be found elsewhere. . . To what, then, do the judges turn? To those principles of reason, morality, and social utility which are the fountain head not only of English law, but of all law" (ibid. 167). 
tural modification in the machinery of our court systems can reduce to a minimum the development of a theological notion of law. ${ }^{54}$

But whatever may be the reasons, when a litigant asks a court to do some new thing which would break into the integrity of its own scheme of things, he must make a clear case and be able to show the way out before he even reaches a competing basis with a familiar method. Ease and certainty of performance are prime qualities of administration, rather than the net results. The most apparent antidote for these conservative factors is found in the changing personnel of the judges. The largest single factor in administration of law after all is the personality of the judge. Says Ehrlich, "There is no guarantee of justice except the personality of the judge."55 All technics must submit to his own. All factors are given weight on his own personal scales. And there is no way to avoid this, nor should a way be sought. As an antidote it is indeed a mild one. It is most remarkable how similar are the reactions of judges and their contemporaries at large. There is not much danger of any judge being either likely or able to depart very far from the beaten path, and if so, there is little danger that he can influence others to follow him. The departures which are made are so few that the slightest ones are sometimes startling. And strange to say that after some "dangerous" judge has worn his life away dissenting and protesting and now and then getting his way, he comes to stand out in the affections of succeeding generations as the one of his day and time who was worth while. With judges on the courts of final resort whose average age is over fifty years, the forces of conservatism should have gages enough. And yet the continuous processionals of both new judges and new problems work astounding changes even over a short period of twenty years. The examination and comparison of the reported cases over several of these periods disclose that despite the slowing down tendencies of all these administrative processes, the control of human conduct is constantly increasing both over widening fields and in discriminating details.

The suggestions here made are reflected in numerous instances. The whole system of equity jurisdiction found its chief sustenance in

${ }^{54}$ In a recent address before the Association of American Law Schools, (1928) 14 A. B. A. J. 71, Professor Herman Oliphant urges "A Return to Stare Decisis." The weight of his argument, however, is rather lodged against what he terms stare dictis. This is nothing more than legal theology, and I subscribe to what he sees in the way of danger here. But I dare suggest that there is no stare decisis of the sort he describes to make a return to. On the other hand it seems to me that the whole force of his paper is a compelling argument against the vices of legal theology and the means through which it is perpetuated, including the major one of stare decisis. It may well be that Professor Oliphant was merely putting an old face on a new form. The courts have made this sort of thing highly respectable, and it has all kinds of diplomatic advantages.

${ }^{55}$ Op. cit. supra note $16,65$. 
the timidity of common law judges towards giving the reliefs which a growing society demanded. In turn when the chancellors had created their own scheme of things they became obsessed with a similar timidity, and equity then became as stale as law. The common law judges were afraid that they would be "flooded with litigation" and find themselves unable to prevent fraudulent use of the court's machinery. Thus they closed the door as far as they could in defamation suits. The abortive development of slander, ${ }^{56}$ seduction, ${ }^{57}$ and this type of suit generally is clearly due to the court's fear of its own power. The courts denied recovery for injuries resulting in death ${ }^{58}$ and then whittled away at every corner the statute which sought to correct this parsimonious development of tort law. ${ }^{59}$ For a long period they refused to allow recovery for the injuries produced through impairment of the physical body through nervous shock unless accompanied with physical impact, ${ }^{60}$ and denied protection to the injured consumer of a manufactured product in absence of privity of contract with the manufacturer. ${ }^{61}$ Only under the guise of protecting a "property" interest will most courts even now interfere to prevent hurt to some of the most valued interests of personality which are identified through the emotions. ${ }^{62}$ Due doubtless to the difficulty in framing a more drastic and yet workable formula, the progress which was being made in the field of deceit and halted prematurely by Derry $v$. Peek, ${ }^{63}$ is just now getting well under way again. ${ }^{64}$ And at this moment our highest court, apparently in fear that its business will grow beyond its capacity, takes every opportunity to let it be known in advance that it will have nothing to do with one of the great preventive remedies which the law has found-the power to declare the rights of parties before injury has taken place-the declaratory judgment. ${ }^{65}$

${ }^{58}$ I Street, Foundations of Legal Liability (1906) 278 et seq.

${ }^{57}$ Ibid. 268 et seq.

${ }^{68}$ Baker v. Bolton, 1 Camp. 493 (1808) ; Conn. Mut. Life Ins. Co. v. N. Y. \& N. H. R. R., 25 Conn. 265 (1856).

${ }^{5}$ See Tiffany, Death by Wrongful Act (2d ed. 1913) §32; Bloss v. Woodson Sanitarium Co., 5 S. W. (2d) 367 (Mo. 1928), N. Y. L. J. No. 86 (July 12, 1928); Mellon v. Goodyear, 48 Sup. Ct. 541 (U. S. 1928).

${ }_{60}$ Throckmorton, Damages for Fright (1921) 34 HARv. L. REv. $2 t \rightarrow$ Bohlen, Right to Recover for Injury Resulting from Negligence Without Impact (1902)

50 Am. L. Reg. 141; Studies in the LAW of ToRTs (1926) 252; Goodrich, Emotional Disturbance as Legal Damage (1922) 20 MICH. L. REv. 497.

${ }^{\circ 1}$ Wilson, The New York Rule as to Nervous Shock (1926) 11 CoRN. L. Q. 512, 515; (1927) 12 CoRn. L. Q. 544; (1927) 13 Corn. L. Q. 151.

${ }^{62}$ See Note (1920) 14 A. L. R. 295; Warren \& Brandeis, The Right to Privacy (1891) 4 Harv. L. Rev. 193; (1926) 10 Minn. L. Rev. 55.

${ }^{63} 14$ App. Cas. 337 (1889).

o4 International Products Co. v. Erie R. R., 244 N. Y. 331 (1927) ; (1927) 12 Conn. L. Q. 539; Seneca Wire \& Mfg. Co. v. Leach \& Co., 247 N. Y. 1, 159 N. E. 700 (1928); see (1928) 37 YaLE L. J. 1141.

${ }^{65}$ Willing v. Chicago Auditorium Ass'n, 48 Sup. Ct. 507 (U. S. 1928). See Borchard, Declaratory Actions as "Case" or "Controversies" (1927) 36 YALE L. J. 845. 
Again and again some of our greatest judges have shown a hostility towards new methods of giving the law's protection, even after their utility has been demonstrated beyond a peradventure by other courts, which can be explained only on the theory that an institution like a court, as well as the individual human mind, may reach a stage in its development when it closes its books and lives alone on its accumulated wealth.

A striking instance of how this factor of administration operates through a long line of cases is found in the "mental suffering" cases. As typical of the cases in which recovery was denied for injury resulting through fright caused by negligent conduct without physical impact is Spade v. Lynn \& Boston Railroad. The court is very clear as to the basis of the decision:

"It would seem therefore that the real reason for refusing damages sustained from mere fright must be something different; and it probably rests on the ground that in practice it is impossible satisfactorily to administer any other rule... . The logical vindication of this rule is that it is unreasonable to hold persons who are merely negligent bound to anticipate and guard against fright and the consequences of fright; and that this would open a wide door for unjust claims, which could not successfully be met."

In a similar type of case, the New York Court of Appeals denied recovery, saying:

"If the right of recovery in this class of cases should be once established, it would naturally result in a flood of litigation in cases where the injury complained of may be easily feigned without detection." ${ }^{\text {"er }}$

Holmes, C. J., in Homans v. Boston Elevated Railway, ${ }^{68}$ in approving the denial of recovery in this class of case said: "It is an arbitrary exception based upon a notion of what is practicable." No other sustainable basis has been found for such holdings, and since the early scare of the courts has subsided, every sort of distinction is employed to get away from the rule in these states. ${ }^{69}$

In the leading case of Hill $v$. Kimball ${ }^{70}$ permitting a recovery in this type of case, the court considered the whole matter closed when it concluded that there could be physical injury through fright. That

${ }^{80} 168$ Mass. 285, 288, 47 N. E. 88,89 (1897).

${ }^{{ }^{\circ 7}}$ Mitchell v. Rochester Ry., 151 N. Y. 107, 110, 45 N. E. 354 (1896).

${ }^{\circ 8} 180$ Mass. $456,457,62$ N. E. 737 (1902).

${ }^{60}$ Clemm v. A. T. \& S. F. Ry., 268 Pac. 103 (Kan. 1928) ; Conley v. United Drug Co., 218 Mass. 238, 105 N. E. 975 (1914); White Sewing Machine Co. v. Leisel, 162 N. E. 633 (Ohio Ct. of App. 1928); McLeod v. Linde Air Products Co., 1 S. W. (2d) 123 (Mo. 1927). See Wilson, op. cit. supra note 61.

76 Tex. 210,13 S. W. 59 (1890). 
there should be a recovery for such physical injury if it were in fact a result of the fright was assumed. Other courts followed this lead but it was not until the Court of King's Bench in Dulieu v. White \& Sons, ${ }^{71}$ repudiated the holding of the Privy Council ${ }^{72}$ that much advance was made in extending liability in this direction. Even in that great case, after the court had done with refuting the argument in cases like Lynn $v$. Spade, it is in vain that one looks for some affirmative basis for the decision. Assuming that the rule allowing recovery in such cases could be administered satisfactorily, why should such a duty be placed upon a defendant? Doubtless there are many good reasons, but they are withheld. In the late case of Hambroke v. Stokes Bros. ${ }^{73}$ in which the English court extended the rule of the Dulieu case ${ }^{74}$ so as to allow plaintiff to recover for the death of his wife caused by her fear for her children's safety, they having been put in jeopardy as she imagined, by defendant's leaving a truck improperly braked at the top of a hill, the majority judges assumed the existence of a duty and placed their discussion on the "breach of duty." Naturally once it is assumed that there is a duty in such cases, the other elements of a tort case are not difficult. It is remarkable, indeed, that such far-reaching extensions of the law as were made in these English cases should have been made with so little apparent consideration of the factors involved. The administrative difficulties, which other judges had discovered, once having been overcome, presumably nothing else was left to be done. What moved the courts to give the plaintiffs protection in these cases is largely a matter of conjecture. Probably in the first case the hardship (the factor of individual justice) of placing so severe a risk upon the plaintiff rather than the defendant whose conduct imposed it was the dominant factor. In the second, this same factor, plus the fact that a stricter accountability. of the operators of motor trucks probably appealed to the court as a means of preventing repetitions of this sort of accident ${ }^{75}$ were very likely determinative. Possibly also the very ease with which the courts demolished the opposing arguments, not realizing that there must still be found some basis of duty, gave the courts an assurance of judgment which finds little substantial basis in the opinions. In fact, as much as the courts have ordinarily said in this direction may be found under the expansible and summarizing term called "public policy," the

71 [1901] 2 K. B. 669. See Gagnon v. Rhode Island Co., 40 R. I. 473, 101 Atl. 184 (1917).

${ }_{72}$ Victorian Ry. v. Coultas, 13 App. Cas. 222 (1887)

${ }^{73}$ [1925] 1 K. B. 141. But see Nuckless v. Tenn. Elec. Power Co., 299 S. W.

775 (Tenn. 1927); (1928) 26 Mich. LAw Rev. 707.

${ }^{74}$ Supra note 67.

${ }^{75}$ This is the "prophylactic factor" to be discussed later. 
starting point for the study of any science of law, rather than its end, as is so generally assumed.

The same sort of situation is found in the extension of the "mental suffering" doctrine to the "telegraph cases" of which the "death message" is typical. The early case ${ }^{76}$ which initiated this doctrine assumed the duty as being imposed by virtue of the telegraph company's offering a public service. That done, there was no further difficulty. The court, however, very emphatically cautions against a loose administration of the rule. Subsequent cases in the same jurisdiction indicate the severe struggle the courts had in determining whether the basis of responsibility was in tort or contract. ${ }^{77}$ This was the struggle in most of the states which adopted the doctrine. ${ }^{78}$ Most courts adopted the contract theory, although the same courts make the point immaterial by a liberal extension of the third-party beneficiary doctrine, and in cases where this will not work fall back upon the tort theory. ${ }^{79}$ Obviously the question of what sort of action is involved falls beside the point. ${ }^{80}$ The important point still remains. Why does the law extend its protection to the emotional interest involved in these cases in absence of physical hurt? It is no easier to resolve this question when liability is considered contractual than when tortious. The answer given by the courts which uphold the doctrine ignore this question except by inference. The soundest basis for such cases is probably found in the prophylactic value it has, and here it has much to commend it. The courts which oppose rest their opposition on the administrative difficulties similar in all respects, except that they are more aggravated here, to those in other "mental suffering" cases. ${ }^{81}$ But the doctrine once being set

${ }^{78}$ So Relle v. Western Union Tel. Co., 55 Tex. 308 (1881). Other courts placed the doctrine on the same basis. See Cashion v. Western Union Tel. Co., 124 N. C. 459, 32 S. E. 746 (1899).

${ }^{77}$ Gulf C. \& S. F. Ry. v. Levy, 59 Tex. 542, 563 (1883) ; Stuart v. Western Union Tel. Co., 66 Tex. 580, 18 S. W. 351 (1885); Horn v. Western Union Tel. Co., 109 Tex. 229, 194 S. W. 386 (1917) ; Western Union Tel. Co. v. Brooks, 279 S. W. 443, 115 Tex. 168 (1926); (1926) 4 Tex. L. Rev. 270, 540.

${ }^{78}$ I STREeT, op. cit. supra note 56,471 , et seq.

${ }^{79}$ Western Union Tel. Co. v. Snodgrass, 94 Tex. 284, 60 S. W. 308 (1901).

${ }^{80}$ Mentzer v. Western Union Tel. Co., 93 Iowa 752, 62 N. W. 1 (1895).

${ }^{81}$ Western Union Tel. Co. v. Wood, 57 Fed. 471 (C. C. A. 5th, 1893); Tyler v. Western Union Tel. Co., 54 Fed. 634 (W. D. Va. 1893); Jones v. Western Union Tel. Co., 233 Fed. 301 (S. D. Calif. 1916); Curtin v. Western Union Tel. Co., 13 App. Div. 253, 42 N. Y. Supp. 1109 (1st Dept. 1897); Western Union Tel. Co. v. Choteau, 28 Okla. 664, 115 Pac. 879 (1911); Note (1914) 49 L. R. A. (N.s.) 206. Lurton, J., in Wadsworth v. Western Union Tel. Co., 86 Tenn. 695, 721 (1888), dissenting said: "Vague and shadowy, there is no possible standard by which such an injury can be justly compensated, or even approximately measured. Easily simulated and impossible to disprove, it falls within all of the objections to speculative damages. . . ." 
afloat, the duty element once having been assumed, it is remarkable what extensions the idea has received. ${ }^{82}$

A recent New York case ${ }^{83}$ illustrates the growth in this direction. A father died aboard ship. His body was embalmed and carried for several days, and then for some unexplained reason, buried at sea while the ship was only twenty-four hours out from New York. Notice could have been given to the plaintiff, a son, but such was not done until after the ship arrived in port. The court allowed a recovery to the son on the ground that the ship was under a duty to notify him and hold the body at his direction, though the court repudiated the contention that the action was based upon a property interest in the corpse. But there can be found in the opinion no trace of the factors which moved the court to allow a recovery here when it repudiates the same idea in the telegraph cases. $^{84}$

Equally interesting is the fact that when such emotional disturbances are caused by intentional conduct on the defendant's part, although physical force is absent, courts unhesitatingly give protection, although they give few hints as to why they do so. ${ }^{85}$ In short, here is an enormous field which is being dealt with, no doubt carefully enough, but with slight intimations from the courts that they give any consideration to the factors involved other than those of administration. Similar observations can be made in many series of cases.

In the celebrated case of Winterbottom $v$. Wright, ${ }^{86}$ Lord Abinger said: "We ought not to permit a doubt to rest upon this subject for our doing so might be the means of letting in upon us an infinity of actions. .. Unless we confine the operation of such contracts as these to the parties who entered them, the most absurd and outrageous consequences, to which I see no limit, would ensue." Alderson, B., in the same case said: "The only safe rule is to confine the right to recover to those who enter into the contract; if we go one step beyond that there is no reason why we should not go fifty. The only real argument in favor of the action is that this is a case of hardship." Rolfe, B., agreed: “. . . it is, no doubt, a hardship upon the plaintiff to be without a remedy, but, by that consideration we ought not to be influenced. Hard cases, it has been frequently observed, are apt to introduce bad law." Thus the

${ }^{82}$ See Wetesen v. Olathe State Bank, 78 Colo. 217, 240 Pac. 689 (1925); (1926) 10 Minn. L. Rev. 434. See also (1922) 6 Minn. L. Rev. 321.

${ }^{83}$ Finlay v. Atlantic Trans. Co., 220 N. Y. 249, 115 N. E. 715 (1917).

${ }^{84}$ Curtin v. The Western Union Tel. Co., supra note 81 .

85 Nickerson v. Hodges, 146 La. 735, 84 So. 37 (1920); Janvier v. Sweeney [1919] 2 K. B. 316; Johnson v. Sampson, 208 N. W. 814, 167 Minn. 203 (1926); $\mathrm{s} \rightarrow$ (1927) 36 Yale L. J. 1148; Boyle v. Chandler, 138 Atl. 273 (Del. 1927); Dunn v. Smith. 74 S. W. 576 (Tex. Civ. App. 1903); Gadbury v. Bleits, 133 Wash. 134, 233 Pac. 299 (1925) ; Note (1925) 44 A. L. R. 429.

${ }_{88} 10$ M. \& W. 109 (1842). 
court was impelled to find no duty although the justice factor strongly demanded judgment the other way. And of the many cases which have dealt with the so-called "dangerous instrumentality" those in which recovery has been denied stick close to these reasons. The so-called exceptions $^{87}$ found in the poison drug cases, ${ }^{88}$ the food cases, ${ }^{89}$ as well as those involving mechanical devices, ${ }^{90}$ have, it is true, about eaten the rule away. But even so, the courts have satisfied themselves largely by repudiating the arguments based upon administrative difficulties, and have given little foundation for their cases to rest upon. The different forms of statement are indicated in a recent Tennessee case $:^{91}$

"Practically all the modern cases are to the effect that the ultimate consumer of foods, medicines, or beverages may bring his action against the manufacturer for injuries caused by the negligent preparation of such articles. ... Some of the cases place the liability on the ground heretofore stated (imminently dangerous to human life or health). Others place it on pure food statutes. Others say there is an implied warranty when goods are dispensed in original packages, which is available to all damaged by their use, and another case says that the liability rests upon the demands of social justice."

Then mark the concluding sentence:

"Upon whatever ground the liability of such a manufacturer to the ultimate consumer is placed, the result is eminently satisfactory, conducive to the public welfare, and one which we approve." (Italics mine.)

Here is a healthy pragmatism which ought to encourage judges to observe the mocking emptiness of much of their theology. Good reasons are seldom far afield for any conclusion which commends itself strongly. But if they cannot be articulated, at least the conclusion can be stated with decisiveness.

There are, of course, other constraining considerations aside from those of administration. But if I were hazarding a guess I should say that the administrative difficulties have always been the first to present themselves to common law courts, and it is only after they have been overcome that the remaining factors are given the recognition which we sometimes feel they should have. These difficulties of administration 1903).

${ }^{87}$ See Huset v. Case Threshing Machine Co., 120 Fed. 865 (C. C. A. 8th,

${ }_{88}^{8}$ Thomas v. Winchester, 6 N. Y. 396 (1852).

so Perkins, Unwholesome Food as a Source of Liability (1919) 5 Iowa L. Buls. 6, 86.

${ }_{90}$ MacPherson v. Buick Co., supra note 36; Heckel v. Ford Motor Co., 128 Atl. 242 (N. J. L. 1925). (1914).

1 Boyd v. Coca Cola Bottling Works, 132 Tenn. 23, 29, 177 S. W. 80, 81 
are always of greatest significance in any new development of the law, and probably stand out more distinctly in other types of cases than they do in negligence cases, as will be illustrated later. Duties must await the court's finding a workable method by which they can be given meaning. Morals, justice, business and purification of the social stream by prophylactic treatment, must all abide the time when the court has adjusted its scheme of things to the exigencies of its internal affairs.

(To Be Concluded)

LEON GREEN

YaLE Law SchoOL 